\title{
Strengthening the Ideational Functions of "Sastrawan" In An Effort for Democratic Governance in Lampung Province
}

\author{
R. Sigit Krisbintoro \\ Lecturer of Goverment Science Department \\ Lampung University \\ Bandar Lampung, Indonesia \\ sigitkrisbintoro@gmail.com \\ Maulana Mukhlis \\ Lecturer of Goverment Science Department \\ Lampung University \\ Bandar Lampung, Indonesia \\ maulanamukhlis1978@gmail.com
}

\author{
Darmawan Purba \\ Lecturer of Goverment Science Department \\ Lampung University \\ Bandar Lampung, Indonesia \\ darmawanpurba1982@gmail.com
}

\begin{abstract}
Many sides must be involved in the development of democracy. In addition to the official political institutions, community groups also have an operationally significant role in realizing democratic governance. One group that has an ideational function is a literally sastrawan groupbecause they have the media to use the language in representing interests, both private and public interests. Many cases prove that sastrawan are also the most important part in seeing and simultaneously undertaking democratic processes especially developing the value of democracy brought by the local traditions. The concepts of strengthening the sastrawan and its relation to the creation of democratic local governance explain the importance of strengthening the aspect of ideational function in maintaining the continuity of a governance. In addition to this relevance found, the fact that literary sastrawanin Lampung have proven to have not made an important contribution to the strengthening of local democracy. In some cases, the claim of democracy is also still a symptomatic polemic and has not found the best solution. Therefore, the purpose of writing this article in addition to explain about how the sastrawan runs its ideational function, more importantly is about how to strengthen the ideational function of sastrawan in an effort to build a coorporated democratic governance.
\end{abstract}

Keywords-ideational functions, sastrawan (literary group), democratic governance.

\section{INTRODUCTION}

\section{A. Background}

Democracy is a part of idea or thought that gives individuals in a group an opportunity to engage in rational processes within it. The progress of democracy, therefore, strictly requires the participation of individuals both formally through formal and non-formal political institutions through other community groups. One group that has a role to participate in building a democratic life especially local democracy is a group of sastrawan (both literary as individuals and as a group). Indeed, sastrawan with their specific activities in their field and/ or art are often considered to have no role in building a democratic life, when in fact they have a very significant role in promoting local culture and encouraging democratization as well as producing literary works that criticize poor democratic practices.

Theoretically, the fundamental concept of democracy entails the merge with parochial local cultural values as Pye (in Sudarsono, 1991: 211) ${ }^{1}$ means. For a country in a transition time such Indonesia, the incorporation of the democracy concepts and the local culture is necessary as part preserving the local culture and facilitating the formation of democracy itself.

As an example, the local traditions of Lampung have known the existence of democracy in their traditions, especially in deliberations to reach agreement. This is manifested in the system of government, the symbol of traditional house and fraternal system, as well as the system to gain power as it is done in the pepadun custom. Therefore, the development of democracy based on local values within the framework of local democracy is a must to do. Besides it is useful to prevent the occurrence of interethnic conflict, and also because the development of local democracy is a demand in the development of regional autonomy.

There are many sides involved in local democratic development in Lampung, such as NGOs, universities (PT) and students as well as other groups. One group that has an ideational function is a sastrawan, since sastrawan have media to use the language. One of the function of language according to Aminuddin (2002: 41) $)^{2}$ is an ideational function that is a function of language to express something presented by the speaker.

In national publication, which was published by Harian Pikiran Rakyat, October 29, 1984 edition, Budiman said that sastrawan should have a mission to help and raise their people. Thisconcerns the literary ideology that seeks to fight the great problems suffered by its people, such as poverty. Welcoming the opinion of Budiman, Haryanto (1985: 131) ${ }^{3}$ suggests that 
the most important thing is that every sastrawanmust be aware of their public interest because the beauty is not universal, the beauty is bound by the dimension of space and time, beautiful in America is not necessarily beautiful in Indonesia. Therefore, what issues develop in public is also an issue considered in the birth of literary works.

The discourse of local democracy development by stimulating the political spirit for society is also brought by the sastrawan through their works and various activities that they have been implemented. Efforts to build the democratization can also be seen in groups of sastrawan who have programs in the implementation of the literary process. The description explains that the sastrawan is also an important actor part in seeing and simultaneously performing democratic processes, especially the values of democracy brought by the local tradition itself. If speaking from the side of literature outward as a work, then the picture that emerges is the relativity of literature between one another. Relativity will be interpreted as a literary work in one hand and political criticism on the other hand.

Data from the Department of Tourism and Culture of Lampung Province indicate that in this province there are many sastrawan (literary group) who individually produce many literary works as well as incorporated in Institutional of Lampung Arts Council (DKL) especially Literary Committee. Lampung Arts Council (DKL) started with the establishment of Lampung local arts board in 1993 as an organization authorized to perform arts performances in Lampung. Establishment of Art Performer Boards of Lampung District to accommodate all artistic potency in Lampung in accordance with Instruction No.5-A of Minister of Home Affairs in year 1993. The formation of Lampung Arts Performance is aimed to catalyze all the potency of local arts of Lampung, while the organization beneath it is Lampung Arts Council (DKL) with the most portion to organize activities around arts in Lampung area.

\section{B. Problem of Analysis}

The problem analysis of the issues discussed in this paper are:

1. How does the role of Lampung Sastrawan in local democracy practice in Lampung Province?

2. How to strengthen the ideational function of Lampung literature in encouraging and strengthening democratic governance?

\section{Research Objectives}

Based on the problem analysis, the research objectivesare:

1. Explaining how role of Lampung Sastrawan in local democracy practice in Lampung Province.

2. Explainingwhat efforts can be made to strengthen the ideational function of Lampung sastrawan in encouraging the strengthening of democratic governance in Lampung Province.

\section{LITERATURE REVIEW}

\section{A. What is Ideational Function?}

A sastrawan is a term for literary sastrawan, poets, literary, intellectual, scholars; or literary scholarship is the language (words, style) used in books (not colloquially), literature, Hindu scriptures, books of science, books, libraries, primbon (contains predictions, calculations, etc. ).

The ideational function is one of the language functions. According to Aminudin (2002: 41), ideational function is the function of language to express something as presented by the speaker. In the context of sastrawan' rolein the implementation of democratic governance, this ideational function can be interpreted as the importance of sastrawan to give ideas and literary works in which containsvalues that can contribute to the realization of democratization. Literary works, therefore, are not only interpreted in the perspective of artworks-ansich but also a social critique with the aim of developing the life of democracy through the ideas it speaks.

\section{B. Who is Lampung Sastrawan?}

Karzi in Cybersastra $(2015)^{5}$ gives a category of who is called as Lampung Sastrawan: First, Lampung sastrawan is a sastrawan who writes literary works in Indonesian and lives in Lampung. In other words Lampung sastrawan is an Indonesian sastrawan living in Lampung. Secondly, the sastrawan of Lampung is a sastrawan who wrote the literary works in the language of Lampung and himself is not domiciled in Lampung. So the sastrawan (literary group) of Lampung is a sastrawan who has two or one of these terms. Lampung sastrawan(literary group) in this case is individual sastrawan or sastrawan who are members of the Arts Council of Lampung.

As the public expectations, Lampung sastrawan is also expected to contribute to the development of local democracy because it has an organization (on one hand) and has the function of conveying ideas (on the other hand). The existence of local democracy value is certainly easier to implement because it is the root of local culture that already exist in Lampung. The sastrawan who are members of the DKL board are expected to record, implement and coach to keep local democracy sustainable. Herein lies the efforts of sastrawan in dismantling activities that can be said not democratic, as well as useful as an effort to develop local democracy in Lampung.

\section{How to Develop Democracy?}

Pye (in Sudarsono, 1985: 23) explains that one of the criteria of political development is the promotion of democracy. Pye also warned that political development should be the same as the creating of democratic institutions and practices. According to Pye (in Haryanto, 1998: 5), elements of equality in the development of politics and democratic practices related to the issue of mass participation and people's 
involvement in political activities, both democratically mobilized and totalitarian.

Broadly speaking, Pye (in Haryanto, 1998: 4), concludes themes related to political development as an equalization of the individual in relation to the political system, the increase in ability of the political system in relation to his/ her environment, and the increase in the distinction of institutions and structures within political system. According to Pye, the three dimensions are in the "foundation and heart" of the development process itself, Pye (1998: 4) asserts that political development is a process of strengthening democratic values and practices. Therefore, the role of Sastrawan (literary group) in the delivery of ideas about politics is actually part of their role in building democracy.

Democracy is not only applied in the life of the state, but in its democracy development also needs to be applied in the life of society and nation. A democratic life is a life that involves people's participation and it is intended for the benefit of the people. In its implementation, democracy can be developed in many ways.

Hoogerwef (1981: 175) ${ }^{6}$ holds that the level of democracy can be achieved in various ways. Means and vehicles to allow group members to influence wisdom are essentially unlimited. General elections are an example of one of these tools. Other tools such as majority rule, also rules to protect minorities, openness, freedom of expression, appeals to decisions, political activity through pressure groups and advisory bodies, and the existence of personal liberty are also a viable means in an effort to improve the life of democracy.

In a local perspective, according to Prihatmoko (Suara Merdeka, Friday 19 November 2004) ${ }^{7}$, the quality improvement of local democracy is influenced by a number of factors commonly referred to as local democratic preconditions. The preconditions of local democracy include: (1) good quality of DPRD; (2) a good, competitive, selective and accountable of DPRD recruitment system; (3) a functioning political party; (4) critical and rational voters; (5) freedom and consistency of the press; (6) solid and consistent NGOs; and (7) civil society empowerment. In this context, the Lampung Sastrawan is categorized into the sixth and seventh points of the precondition.

\section{What is Literature and Democracy Relations?}

Although it is not directly related, democracy cannot be separated from literature because literature is one way in expressing democracy for example in a literary work of poetry or prose. A more free poetry, sometimes also contains extensive interpretations. While prose is a bit more organized with all forms and accompaniment of the reading sign. Democracy in Indonesia can be construed by literature, whereas the idea of democracy can be similar to a poem that has freedom in its interpretation. But democracy in its form is a prose which we must obey for itsevery spelling.
To explain a literature, it can be analyzed in Soeratno's opinion (in Jabrohim, 2002: 9) ${ }^{8}$ as follows:

"The term literature is used to refer to the cultural phenomenon that can be found in all societies, although socially, economically and religiously its existence is not a necessity. The literary criteria that exist in a society do not always match the literary criteria that exist in other societies. "

Seeing the literary discourse in politics, Haryanto (1985: 40) gave the following review:

"Literature is never released from politics or is never separated from the political interests of certain parties in the society concerned. The relationship between literature and politics is not merely as two independent things that have contacts at the edge of each region but also complementary between the two ".

It is clear that sastrawan have responsibility for societal, political, democratic, and cultural development issues because sastrawan are inseparable from their social environment. In the context of the development of local democracy sastrawan have a role at the level of carrying out and explaining to the community about the symptoms occured of the governance.

\section{METHODOLOGY}

This research is a qualitative research type. The data collection procedure as an attempt to limit the focus of research based on two main problem formulations and gathering information is done through interviews and document collection. In-depth interviews were conducted with the Chairman of the Arts Council of Lampung, as well as three sastrawan in Lampung. While the qualitative documents collected are data of literary works that have been done by sastrawan, especially those related to social criticism of the practice of governance in Lampung Province.

After the stages of data collection is passed, qualitative data analysis is done to generate descriptive data analysis without using the numbers. Everything that information expresses both written and spoken is learned as a whole. In other words the research not only reveals the truth, but also understands the truth. To obtain the confidence level of the research result, referring to Creswell's opinion (2010: 277) ${ }^{9}$ the validity is tested through the triangulate and invited an auditor (external auditor) to review the overall research result. In this context, it is a Lampung culturalist who is also an academic.

\section{RESULTS AND DISCUSSION}

\section{A. Democracy Practice Based on Lampung Culture}

Lampung has long known local democracy as it is practiced in the history of kingdom (e.g. Kingdom of Tulang Bawang 
and Skala Brak Kingdom) or unity (keratuan) (e.g KeratuanDarah Putih and Keratuan Pubian) that exist in this province as well as the values that become the guidance of Lampung society that is Piil-Pesenggiri in which there are elements or positive values of life. Lampung cultural values teachethe people how to solve problems by deliberation and consensus as well as in decision making so that the indigenous people of Lampung can live side by side with migrant communities. Although different, ethnic communities of Lampung can live in peace and in mutual respect among the ethnic diversity of the existing population (Sai Bumi Ruwa Jurai).

There are many views about the journey of local democracy in Lampung which all affirm that Lampung culture is an empirical practice of local democratic values. The thought that is in line with the conception of democracy has actually existed for a long time, it is for example expressed in the History of Lampung Region issued by the Regional Office Depdikbud Lampung Province (1997/ 1998: 101) ${ }^{10}$. Still from the same source History of Lampung (1997/ 1998: 101) noting as follow:

\begin{abstract}
"the cultural system, also called the clan system, is a longestablished system of village governance, especially in the northern areas that have a culture, the system focuses on deliberation and consensus with decentralized autonomy in its implementation. The system of government based on this declaration is actually not in accordance with the will of the Dutch government. But the Dutch government can not do much because the customs of Lampung are still held firm by the people of Lampung. "
\end{abstract}

The nature of using musyawarah or deliberation as a reflection of democracy is also used in conflict resolution either between fellow tribe or clan or between tribe or other clan. Hadikusuma (1990: 166) describes the following:

"If there is still a dispute between one with the other in the daily association then the way of completion that is pursued should be in accordance with Lampung's personality, resolved in the atmosphere of customary court (dorpjustitie) by deliberation and consensus peacefully with the principle of kinship"

According to Hadikusuma (1990: 176) ${ }^{11}$, in terms of cooperation or joint endeavor in form of organizations or individuals, they prefer to choose to work together or helping each other in a smooth and respectable work. More explicitly according to Hadikusuma et al (1996: 18), the system of deliberation used by Lampung tribe is described in the explanation of Lampung traditional house which one of its functions is as a place of deliberation i.e pusiban or siba place (facing place, meeting place, or place of councils sitting in order for deliberation). Meanwhile, the values upheld by the Lampung community namely Piil Pesenggiri proved to be values that are in line with the value of democracy.

According to Hadikusuma (1990: 15), Piil Pesenggiri contains the following components:
- Pesenggiri, meaning unyielding, does not want to lose in attitude, actions and behavior. Juluk Adek, has a meaning to like having good name and honorable title.

- Meet Nyimah, meaning giving and receiving in an atmosphere of joy and sorrow.

- Nengah Nyappur, meaning sociable and deliberate in solving all problems.

- Sakai sambayan, meaning to help and cooperate in kinship and neighborhood.

Operationally, pesenggiri contains the principle of freedom and sovereignty of behaviour as well as guarantee the establishment of justice. Nemui nyimah contains the principle of pluralism and tolerance. Nengah nyappur embodies consensus and conciliate principles and regularly conducts leadership turnover. Meanwhile sakai sambayan it contains the principle of limiting violence in the process of democracy and the implementation of peaceful change of society. The history of Lampung civilization since the pre-independence era until now has shown that the operationalization of Piil Pesenggiri as a democratic value shows how it has a positive impact on the sustainability of democratic governance in the residential (locally) and in official government (districts).

\section{B. Lampung Sastrawan' Efforts in Local Democracy Development}

The values of democracy in the principle of life Piil Pesenggiri in Lampung certainly in line with the value of the community, including sastrawan in it. The sastrawan (as an individual) certainly has the responsibility of literature. Nevertheless, in addition to producing literary works, the sastrawan also has the responsibility to pay attention to social dynamics, as mentioned by Aritonang (in Haryanto, 1985: 256), that sastrawan should be concerned with issues that are not fulfilled the sense of justice in the midst of the society. If the sastrawan does not heed the reality that is in the field then the real literary has been in an alienation itself. In that context, sastrawan must have a view as well as attitude or action towards and about democracy.

To see the views of Lampung sastrawan on the world of politics and democracy can be traced through Karzi's view (Cybersastra, 2002) as follows:

"If politics fouled, then literature purifies it. The phrase $b y$ John F. Kennedy is so famous, that literatures then become legitimated hygiene, and then people consider literary works as works that can articulate freedom, conscience, and morality. Read literature so that the eye of the heart can be honed with human values, for good literature can invite people to reflect on a journey of life, not with black-and-white glasses, wrongs, or sins, but full of causal background and tolerance customary".

Further Karzi (Cybersastra, 2002: 8) describes the following: 
"The difference between sastrawan and politicians is, if politicians struggle to gain power, sastrawan work to develop a more peaceful life, harmonious and full of humanitarian considerations, because literature is the life side contained in the form of writing. As readers of course we can distinguish which are works of literature and which are political writing. Obviously there is different way of writtingbetween two, so no need to worry readers will think that lies are as a form of literary work."

The two views above show that individually there is a high awareness that the world of literature that they are engaged in is very likely to contribute to the development of local democracy. As for the attitude or action, Lampung literary efforts in the development of local democracy has actually been done through many ways such as by embracing different customary and religious leaders from the indigenous people of Lampung and also respect each other and do not discriminate ethnicity, race and religion in all cultural activities. One of the figurative words commonly used by the sastrawan (literary group) of Lampung and Lampung people in everyday life reads "Muhmanah Wewah Pudak" which means in everyday life we begin to smile to someone. Another effort made by Lampung Literary is by doing various activities intended to embrace different people tribe, race, and religion so as to prevent the occurrence of conflict.

In particular, the value of local democracy based on the Piil Pesenggiri principle strived by the sastrawan of the Arts Council of Lampung (DKL) is reflected in the following analysis (Satria, 2016: 76) 12.

\section{a. Pesenggiri}

Pesenggiri means abstinence, not to be outdone in attitude and behavior. The reflection illustrates the existence of Lampung customs that can not be in the pressures of others. In other words, the freedom of relationships built by DKL boarders towards Pesenggiri because as an organization DKL is not under any organizations and gives freedom to other organizations.

Dhal theory says that the sovereignty of society is as individuals and social beings so that these valuesdevelop along with the movement and shift in the modern social dynamics. If it refers to the explanation of Dhal theory then the meaning of pesenggiri in local democratic values piil pesenggiri in line with the theory of Dhal, where the people of Lampung have a habit that can not be in pressure or can be regarded as a free or sovereign human. With the inclusion of Pesenggiri value in DKL organization, DKL is expected to be a free organization without any intervention and interest.

b. Nemui Nyimah

Nemui Nyimah means accepting and giving in an atmosphere of joy and sorrow. The process of Nemui Nyimah is explained in the presence of personality to accept others under any circumstances. In the context of stewardship, DKL provides an opportunity to anyone to become a DKL board formed by the Format team. Mayo argues that democratic values are simply described with an indication of solving problems peacefully and voluntarily, ensuring peaceful change, regular rulers, minimal coercion, diversity, justice and freedom. In that context, the values of Piil Pesenggiri Nemui Nyimah likes to give in any atmospheres of likes and sorrows in harmony with the value of democracy. With the inculcation of the values of Piil Pesenggiri Nemui Nyimah, it is expected DKL organization can accept anyone to become chairman and board members democratically and change regularly.

\section{c. Nengah Nyappur}

Nengah Nyappur means sociable and deliberative in solving all problems. Deliberation of consensus is a deliberation which represented by pemangku adat to solve a problem. In the context of DKL, such principles can be seen from the decision-making process at DKL which has four levels of deliberation. Mayo argues that democracy values are simply described as resolving issues peacefully and voluntarily ensuring peaceful change, regular change of rulers, minimal use of coercion, diversity, enforcing justice, and freedom are also in harmony with the values of Nengah Nyapur which means sociable and consensual in solving all the problems. With the inculcation of the values Piil Pesenggiri Nengah Nyapur, DKL organization in terms of decision making can be solved by consultation.

\section{d. Sakai Sambayan}

Sakai Sambayan means helping and working together in kinship and neighborhood. The value of Sakai Sambayan is also encountered in several organizational mechanisms in DKL, one of them in the preparation of work programs in DKL The consideration that other people can benefit from an activity undertaken by DKL is a Sakai Sambayan process. In DKL, in addition to the community it is also encountered Sakai Sambayan process among sastrawan relationship with other artists so that in DKL sastrawan and artists complement each other and fill among fellow DKL board to create a harmonious organization within the organization.

In addition to the efforts of sastrawan in institutional activities in DKL, several examples of works devised to develop a local democracy personally as a sastrawan for example making a short story entitled "Self-Esteem" (Udo Z Karzi's work published in Teknokra newspaper) in which contains the value of local democracy Pesenggiri explaining that the people of Lampung have self-esteem and do not want to be trampled. In addition, there are literary works that reflect the value of local democracy Nemui Nyimah entitled "Maha Duka Aceh" which in it reflects the value of Nemui Nyimah which like to give in the atmosphere of grief and love. There is also the value of Nengah Nyampur contained in the literary work entitled "How I Lost", which in it reflects the value of Nengah Nyampur is like hanging out and deliberating, as for the literary work that reflects the local democratic values Sakai Sambayan entitled "Daun-Daun Jatuh" which reflects the value 
local democracy Sakai Sambayan which means to help and work together. The phenomenal work in the case of the sastrawan' role in utilizing ideational function is Udo Z Karzi (in his literature "Ke Negara Batin Mamak Kenut Kembali") who was succeeded in getting the "Rancage Award".

\section{The DKL irony in Organizational Democracy Practices.}

Although personally there is an awareness that the values of Piil Pesenggiri are in harmony with the value of democracy in the institutions of the sastrawan (in this case in DKL), the focus of this chapter is how the Literary Society's organization in DKL practices the value of democracy in its organizational governance. This study is important because Lampung sastrawan who is a board of DKL also has responsibility and should be able to make efforts of the local democracy development process, local democracy in this research focuses on the analysis of Piil Pesenggiri which became the culture of Lampung people and cultural system that became the government system of Lampung people that emphasized on deliberation and consensus with decentralization of autonomy in its implementation.

Satria's research (2016: 73) suggests that the DKL leadership turnover method is slightly different from that of several NGOs or other artist organizations. In the research revealed that the DKL leadership or management turnover process using the Formation Team method is not a direct election. Clearly the stage of change of leadership of DKL as follows:

a. The old management organizes artists discussions by inviting some artists who are considered competent in their fields;

b. On the artists deliberation day artists, the participants discussed the old reports and the Articles of Association (AD) and the Bylaws (ART);

c. For the election process of the chairman, daily chairman, vice chairperson, and secretary until the board under it submitted to the Formation Team formed by the participants;

d. Furthermore, the formative team that selects the next period board will be assisted by the DKL Honorary Board.

This switching method is not ideal, because it tends to manipulate. Since the election of the chairman is not transparent and not direct, so this method of leadership turnover is not appropriate for a modern organization. Such a leadership turnover is deemed not to be ideal if it is related to Dhal's (1985: 10) ${ }^{14}$ that ideal democracy must meet five criteria, namely equality of suffrage, effective participation, truth exposure, final control of the agenda, and coverage. With these five criteria full fill, the implementation of democracy can be said to meet the ideal of a democratic system vice versa.

In addition, DKL is also different from the Jakarta Arts Council (DKJ) or the Riau Arts Council (DKR) or other Regional Arts Council which does not place an official as chairman, because in DKL a chairman of the periods that has passed to the present the general chairman is always from among officials or persons which are directly in contact with officials. In terms of function, the general chairman has neverserved directly because of the symbolic position only. While the one organizing the organization is a daily chairman. In the current period 2015-2019, the general chairman of DKL is a governor governing wife (Ny. Aprilani Yustin Ficardo) and in the previous period held by a sister governor who is also serving or in duty (Syafariah Widianti).

The decision-making process in DKL is also considered not reflecting local democracy wherein the DKL decision-making only involves the chairman of the board (chairman of the committee) and it is conducted privately. It is in the contrary to the local democracy Lampung Piil Pesenggiri one of them is Nengah Nyampur which has the meaning of socializing and deliberation to solve the problem. In this context, Nengah Nyappur in decision-making should involve all members of each committee, so that the resulting decisions can reflect the values of local democracy because it accommodates the common will.

The irony as mentioned above, is made even worse by the numbers of sastrawan who do not know that there is a link between universal democratic values and local level democracy (Lampung). This condition illustrates that awareness of local democratic development efforts is not intensively implemented, and even it tends to have no consistency towards the development of local democracy. In addition to the lack of concentration on the development of local democracy, the obstacles that arise are also due to organizational mechanisms that provide opportunities for differences among the board that so often do not reflect democratic attitudes.

Attitudes and views differences that occur in DKL implicate in the ineffectiveness of the organization mechanism, another problem is, DKL's less efforts towards the development of local democracy also DKLs'sastrawan lack of attention to the programs that focus on the re-appointment of local culture and ways to socialize it to the community, because most programs the DKL drafted only focused on artistic activities. There are even some sastrawan in DKL who consider taboo to incorporate political and democratic elements in art and cultural activities undertaken.

\section{Strengthening Ideational Functions of Sastrawan.}

Halliday (1974: 105) stated the existence of ideational, interpersonal, and textual functions in the use of language; including literature in it. Ideational function refers to the function of language as a vehicle in expressing 'something'. The expression of 'something' must be accompanied by a representation of something that is going to be expressed because it is only through representation that speakers of a language can understand the description of the meaning in line with the 'thing' to be expressed. 
Furthermore, languages also work interpersonally. Refers to the language functions that can be used to provide responses, judgments, reactions, or to convince. To Halliday (1974: 106) $)^{13}$, "the interpersonal function thus subsumes both expressive and the conative." In the event of communication the use of such sentences, as well as the utilization of interpersonal functions, is also related to the way of speaking, the context of narrative and the relationship between the speaker and the responder. That is why the existence of interpersonal functions also describes an interactive relationship between speakers with something that is expressed, with the responders, as well as with the expected effect of the speech.

Ideational and interpersonal functions will not ta ke placewithout a vehicle forming the text. For that reason both functions above must be referred to the third function, namely the textual function. To Halliday (1974: 107), "a text is an operational unit of language". The operation of the language can not be separated from the cultivation of languageelements, for example, the selection of words and their wording is not solely determined by grammatical rules internally but also determined by the fulfillment of language functions in human relations, whether it refers to ideational, interpersonal, or textual functions. Strengthening ideational function, therefore, would be more leverage if the focus is more on the sastrawan as an individual than strengthening the organization of the sastrawan.

\section{CONCLUSION AND CLOSING}

Values in the Culture of Lampung, Piil Pesengiri is in line with democratic values and has long been practiced in local governance. Pesenggiri contains the principle of freedom and sovereignty behave and ensure the establishment of justice. Nemui nyimah contains the principle of pluralism and tolerance. Nengah nyappur embodies consensus and consensus principles and regularly conducts leadership turnover. While in sakai sambayan contains the principle of limiting violence in the process of democracy and the implementation of peaceful change in the society. Nevertheless, there is an imbalanced practice between sastrawan as individuals who are able to produce literary works that express 'some critics' compared to sastrawan as group members in the Lampung Arts Council which put up literary activities in the development of local democracy that tend to be unneutral.

Efforts to develop local democracy have been done by sastrawan personally by making literary works and work programs that try to develop local democratic values Piil Pesengiri. For example introducing a culture of local democratic values through poetry, march, and the making of books containing local democratic values. Evidently, the work of the individual gained much appreciation not only in the context of artwork but also as a motivation for the development of democratic governance. However, the role of literature in the DKL institution is still far from the practice of that ideal. The board turnover, the determination of the chairman, and the compilation of the work program have not reflected the application of the cultural values of Lampung nor the democratic values that tend to not dare beingneutral from the interests of the government.

In that context, the reinforcement sastrawan ideational function most likely to be developed through individual roles. Sastrawan as individuals is perceived to have a more maximal role in the context of producing literary works that can encourage the strengthening of local democracy. Therefore, encouraging the role of sastrawan personally to strengthen their ideational function will assure the sastrawanbetter role in promoting the creating of democratic local governance; especially for and in Lampung Province.

\section{REFERENCES}

[1] Sudarsono, Juwono (ed). "Pembangunan Politik dan Perubahan Politik: Sebuah Bunga Rampai”. Jakarta: Yayasan Obor Indonesia. 1991.

[2] Aminuddin, etc. "Analisis Wacana, Dari Linguistik Sampai Dekonstruksi”.Yogyakarta: Pusat Studi Kebudayaan Universitas Gajah Mada dan Penerbit Kanal. 2002. p. 41.

[3] Haryanto, Ariel. "Perdebatan Sastra Kontekstual". CV. Rajawali, Jakarta. 1985. p. 131.

[4] Dinas Pariwisata dan Kebudayaan Provinsi Lampung. "Profil Pariwisata, Kebudayaan, dan Kesenian Provinsi Lampung. 2015.

[5] www.cybersastra.com

[6] Hoogerwerf. "Politikologi". Erlangga, Jakarta. 1981. p. 175.

[7] Prihatmoko. Suara Merdeka Jumat 19 Nopember 2004). Published.

[8] Jabrohim. "Metodologi Penelitian Sastra". Hanindita, Jogyakarta. 2002. p. 9 .

[9] Creswell, John W. 'Research Desigin, Pendekatan Kualitatif, Kuantitatif, dan Mixed (Third Edition). Transleted Akhmad Fawaid. Pustaka Pelajar, Yogyakarta. 2010. p. 277.

[10] Kantor Wilayah Departemen Pendidikan dan Kebudayaan Provinsi Lampung. Sejarah Provinsi Lampung. 1997. p. 101.

[11] Hadikusuma, Hilman, etc. "Masyarakat dan Adat Budaya Lampung". 1996. Mandar Maju Bandung. p. 176.

[12] Satria, Rizki. "Upaya Sastrawan Lampung Dalam PengembanganDemokrasi Lokal Dengan Prinsip Piil Pesenggiri”. Skripsi FISIP University of Lampung, Bandar Lampung. 2016. p. 76-79.

[13] Halliday, MAK. "Explorations in the Functions of Language". London: Edward Arnold Publisher. 1974. 